\title{
Effect of Growth Regulators on Germination and Vigor of Lentil Seeds
}

\author{
M. A. I. Pulok ${ }^{1 *}$, M. M. Rahman ${ }^{2}$, M. N. Haque ${ }^{2}$, R. Chakraborty ${ }^{2}$ and M. S. Ali ${ }^{2}$ \\ Dept. of Seed Technology ${ }^{1}$ \\ Dept. of Agronomy ${ }^{2}$ \\ Sher-e-Bangla Agricultural University, Dhaka, Bangladesh
}

Corresponding author*: kbdpulok@gmail.com

\begin{abstract}
An experiment was carried out to evaluate the effect of growth regulators viz., Gibberellin $\left(G A_{3}\right)$, lemon juice and tamarind leaf extract on germination and vigor of lentil seeds. The experiment was conducted with BARI Masur-4 cultivar, and three growth regulators: gibberellin, lemon juice and tamarind leaf extract were used. Three concentrations of gibberellins (10, 20 and $30 \mathrm{ppm})$, three concentrations of lemon juice (2, 4 and $6 \%$ ) and three concentrations of tamarind leaf extract (0.05, 0.1 and 0.15\%) with two soaking time duration: 6 and 12 hours and control were used. Gibberellin $\left(G A_{3}\right)$ improved germination percentage, seedlings length, dry matter, germination index and vigor index of lentil. Lemon juice enhanced germination percentage, seedling length, vigor index and germination index in lentil. Tamarind leaf extract increased the germination percentage, vigor index and speed of germination in lentil. In comparison with plant growth regulators, length and weight was found to be positively correlated and in most cases relationships were significant.
\end{abstract}

Key words: Lentil, growth regulators, germination and vigor

\section{Introduction}

Pulses are important legume crops in Bangladesh because of their importance in food, feed, and cropping systems. It contains about twice as much protein as cereals. It also contains amino acid lysine which is generally deficient in food grains (Elias et al., 1986). In Bangladesh, lentil placed second position among the pulses according to area and production but stand first in terms of usage (Afzal et al., 1999). The term plant growth regulators (PGRs) cover the broad category of organic compounds other than nutrients. A large number of synthetic compounds exhibit PGR- like activity and marketed for commercial use, particularly naphthalene acetic acid (NAA), $\mathrm{GA}_{3}$, Auxin etc. The impact of PGRs in manipulating physiological processes in crop production include germination, vigor, nutrient uptake from soil, photosynthesis, respiration, partitioning of assimilate, growth suppression, defoliation and postharvest ripening (Rahman and Nath, 1993; Kathiresan and Balasubramanian,1995). Poor germination and subsequent establishment of different pulse seed is a general problem in grain pulse production. Improvement in germination capability and increasing seed vigor might be one option to make the growing pulse seedling more competitive with those of weeds. There are evidences that different natural and synthetic growth regulators improve seed germination and seedling vigor of many crops (Mohanty and Sahoo, 2006; Renugadevi and Vijayageetha, 2009). These growth regulators may be of natural origin or synthetic. The growth regulators both from organic (Emblica officinalis, lemon, etc.) and inorganic sources along with some traditional growth regulators were tried to increase the germination and vigour 
of different pulse seeds. In Bangladesh, a good number of experiments have been undertaken in many field and horticultural crops on gibberellic acid to evaluate germination and vigor seed and it was found to have increased the growth and yield of various economically important crop plants including cereals, legumes, vegetables, fibers, oilseeds, medicinal plants, beverages, narcotics etc. (Chowdhury, 1978; Hussain et al., 1980). This growth regulator was found to increase the growth and yield of many field and horticultural crops (Lakshmamma and Rao, 1996; Karim, 2005). Works regarding the effect of growth regulators on pulse seed germination is very limited worldwide and is either lacking or scanty under Bangladesh condition. The present investigation has been undertaken to find out the effect of growth regulators individually or in combination on the following aspects of lentil: (i) to increase the seed germination of lentil seeds under soaking in varying concentrations of different natural and synthetic growth regulators, (ii) to evaluate vigor of different lentil seeds under soaking in varying concentrations of different natural and synthetic growth regulators and (iii) to evaluate seedling parameters of lentil under soaking in varying concentrations of different natural and synthetic growth regulators.

\section{Materials and Method}

The research work related to determine the effect of organic and inorganic growth regulators on germination and vigor which was conducted in the Seed Quality Laboratory, Institute of Seed Technology, Sher-e-Bangla Agricultural University, Dhaka-1207 during November 2011 to March 2012. Furthermore this experiment was done within the project entitled 'Study on the Agronomic Seed Health and Quality Testing and Improvement” by Japan Society for Promotion Science (JSCS) (Yamagata University) and University Grants Commission of Bangladesh.

The experimental area was situated at $23^{\circ} 77^{\prime} \mathrm{N}$ latitude and $90^{\circ} 33^{\prime} \mathrm{E}$ longitude at an altitude of 8.6 meter above the sea level. The genetically pure and physically healthy BARI lentil-4 seeds were collected from of Bangladesh Agricultural Research Institute (BARI), Gazipur. $13 \mathrm{~cm}$ diameter sized pots wereu sed to perform the study. A two factor experiment was laid out in a randomized complete block design (factorial) with three replications. Seeds were soaked in different concentrations of three growth regulators: Lemon juice (Citrus limon), Tamarind leaf extract (Tamarindus indica) and Gibberellin $\left(\mathrm{GA}_{3}\right)$.

This experiment consisted of 21 treatments, which are as follows, $S_{0}=$ Without soaking, $S_{6}=$ Soaking in distilled water for 6 hours, $\mathrm{S}_{12}=$ Soaking in distilled water for 12 hours, $\mathrm{L}_{1} \mathrm{H}_{6}=$ Soaking in lemon juice $2 \%$ for 6 hours, $\mathrm{L}_{1} \mathrm{H}_{12}=$ Soaking in lemon juice $2 \%$ for 12 hours, $\mathrm{L}_{2} \mathrm{H}_{6}=$ Soaking in lemon juice $4 \%$ for 6 hours, $\mathrm{L}_{2} \mathrm{H}_{12}=$ Soaking in lemon juice $4 \%$ for 12 hours, $\mathrm{L}_{3} \mathrm{H}_{6}=$ Soaking in lemon juice $6 \%$ for 6 hours, $\mathrm{L}_{3} \mathrm{H}_{12}=$ Soaking in lemon juice $6 \%$ for 12 hours, $\mathrm{T}_{1} \mathrm{H}_{6}=$ Soaking in tamarind leaf extract $0.05 \%$ for 6 hours, $\mathrm{T}_{1} \mathrm{H}_{12}=$ Soaking in tamarind leaf extract $0.05 \%$ for 12 hours, $\mathrm{T}_{2} \mathrm{H}_{6}=$ Soaking in tamarind leaf extract $0.1 \%$ for 6 hours, $\mathrm{T}_{2} \mathrm{H}_{12}=$ Soaking in tamarind leaf extract $0.1 \%$ for 12 hours, $\mathrm{T}_{3} \mathrm{H}_{6}=$ Soaking in tamarind leaf extract $0.15 \%$ for 6 hours, $\mathrm{T}_{3} \mathrm{H}_{12}=$ Soaking in tamarind leaf extract $0.15 \%$ for 12 hours, $\mathrm{G}_{1} \mathrm{H}_{6}=$ Soaking in gibberellin 10 ppm for 6 hours, $\mathrm{G}_{1} \mathrm{H}_{12}=$ Soaking in gibberellin 10 ppm for 12 hours, $\mathrm{G}_{2} \mathrm{H}_{6}=$ Soaking in gibberellin $20 \mathrm{ppm}$ for 6 hours, $\mathrm{G}_{2} \mathrm{H}_{12}=$ Soaking in gibberellin $20 \mathrm{ppm}$ for 12 hours, $\mathrm{G}_{3} \mathrm{H}_{6}=$ Soaking in gibberellin $30 \mathrm{ppm}$ for 6 hours and $\mathrm{G}_{3} \mathrm{H}_{12}=$ Soaking in gibberellin $30 \mathrm{ppm}$ for 12 hours.

100 seeds in each pot were placed. Performance of natural and synthetic growth regulators was evaluated on the basis of laboratory germination test by collecting different germination parameters e.g. germination percentage (\%) and seedling growth parameters i.e. shoot length, shoot fresh and dry weight, vigor index, speed of germination and germination index. For recording length, 20 seedlings in each pot were selected randomly. For assessing fresh and dry weight, seedlings of whole pot were considered. Germination 
meant when either cotyledons or plumule emerged above the sand upper surface. For dry weight determination, the seedlings were removed and dried in an electric oven at $70^{\circ} \mathrm{C}$ temperature for 48 hours.

The data obtained for different studied characters were statistically analyzed following the analysis of variance techniques by using MSTAT-C computer package programme. The significant differences among the treatments means were compared by Least Significant Difference (LSD) at 5\% level of probability (Gomez and Gomez, 1984).

\section{Results and Discussion}

\section{Effect on germination percentage of lentil}

Germination of lentil started from three days after sowing (DAS) which ranged from zero to 19.02\%. (Table1). The non-soaked treatment always showed the lowest germination percentage and most of the tamarind treated seeds did not germinate while germination improved due to soaking. However, the improvement due to soaking for 12 hours was not so pronounced as compared to those soaked for 6 hours. The six hour soaked $\mathrm{G}_{2}$ treatment showed the highest germination percentage. Other treatments showed lower germination percentage than the seeds soaked for six hours $\left(\mathrm{S}_{6}\right)$. At 4 DAS germination ranged from $7.98 \%$ (non-soaked) to $84.82 \%\left(\mathrm{G}_{2} \mathrm{H}_{6}\right)$ and higher germination percentage observed at 6 DAS although this trend was continued by $\mathrm{G}_{3} \mathrm{H}_{12}$ at the later stages also. In case of Gibberellic acid and tamarind, seeds soaked for 12 hours showed higher value than those soaked for 6 hours in most of the cases.

\section{Effect on seedling length of lentil}

Seedling length has been found to be influenced by lemon juice and tamarind leaf extract. It was found that different seedling length ranged from $0.99 \%$ (with $\mathrm{S}_{0}$ ) to $3.09 \%$ (with $\mathrm{G}_{2} \mathrm{H}_{12}$ ) (Figure 1). At 5 DAS, the mean seedling length ranged from $1.49 \mathrm{~cm}$ to $3.097 \mathrm{~cm}$ with LSD 0.3259 at $0.05 \%$ level of significance. At $7 \mathrm{DAS}, \mathrm{G}_{1} \mathrm{H}_{12}$ showed the highest seedling lengths $(6.61 \mathrm{~cm})$ whereas, $\mathrm{T}_{1} \mathrm{H}_{12}$ and $\mathrm{L}_{1} \mathrm{H}_{12}$ showed the lowest value (2.6) There are evidences that the seedling length is greatly influenced by the application of growth regulartors. Lakshmamma and Rao (1996) found that the black gram seedlings length on spraying with 5-20ppm NAA at flowering stage was progressively increased. Uddin et al. (1994) by spraying 500ppm NAA on the foliage of lablab bean at 72 DAS, observed a significant increase in internodes length. It was observed that even by soaking seeds in 25-50 ppm NAA, seedling length of soybean was increased (Maske et al., 1997). However, the seedling length was found to decrease when seeds were soaked in highly concentrated $(150 \mathrm{ppm})$ NAA solution. Similar result was found in this study. Higher concentration of different growth regulators reduced the seedling length. In case of gibberellic acid higher concentration showed remarkably reduced length of lentil seedlings. At 10 DAS, the treatments did not show appreciable difference in comparison to $S_{12}$ but the difference was noticed when compared with $\mathrm{S}_{0}, \mathrm{~S}_{6}$ and $\mathrm{L}_{3} \mathrm{H}_{12}$ (6\% lemon juice with12 hours soaking). Probably at higher concentration (6\% or more) of lemon juice with 12 hours reduced the cell elongation of seedlings which intern reduced the seedling length. The analysis of variance revealed highly significant differences among the treatments with respect to seedling length.

\section{Effect on seedling dry matter of lentil}

At 3 DAS, the lowest seedling dry matter was found with $\mathrm{S}_{0}(0.21 \mathrm{~g})$ while the highest with $\mathrm{T}_{1} \mathrm{H}_{12}(0.45 \mathrm{~g})$ and second highest with $\mathrm{T}_{2} \mathrm{H}_{12}(0.43 \mathrm{~g})$ respectively (Table 2). For $\mathrm{G}_{2} \mathrm{H}_{6}(0.37 \mathrm{~g})$ and $\mathrm{G}_{3} \mathrm{H}_{12}(0.38 \mathrm{~g})$ 
treatment, moderately higher dry weight as compared with other treatments was observed. Lowest dry matter content was found in case of lemon juice.

Table 1. Effect of lemon juice, tamarind leaf extract and gibberellin on germination percentage of lentil seeds

\begin{tabular}{|c|c|c|c|c|c|}
\hline \multicolumn{6}{|c|}{ Germination $(\%)$} \\
\hline Treatments & 3DAS & $4 \mathrm{DAS}$ & 6 DAS & 7 DAS & $10 \mathrm{DAS}$ \\
\hline $\mathrm{S}_{0}$ & 0.00 & 7.98 & 44.44 & 52.77 & 55.91 \\
\hline $\mathrm{S}_{6}$ & 1.38 & 14.46 & 82.11 & 84.88 & 88.74 \\
\hline $\mathrm{S}_{12}$ & 1.81 & 23.51 & 79.17 & 84.25 & 84.57 \\
\hline $\mathrm{L}_{1} \mathrm{H}_{6}$ & 2.75 & 15.52 & 57.00 & 39.75 & 53.62 \\
\hline $\mathrm{L}_{1} \mathrm{H}_{12}$ & 0.30 & 15.11 & 58.12 & 38.34 & 60.00 \\
\hline $\mathrm{L}_{2} \mathrm{H}_{6}$ & 3.10 & 17.25 & 28.63 & 31.40 & 34.84 \\
\hline $\mathrm{L}_{2} \mathrm{H}_{12}$ & 1.17 & 9.34 & 25.81 & 25.63 & 28.12 \\
\hline $\mathrm{L}_{3} \mathrm{H}_{6}$ & 0.00 & 12.26 & 35.34 & 39.69 & 51.72 \\
\hline $\mathrm{L}_{3} \mathrm{H}_{12}$ & 0.00 & 13.05 & 29.59 & 27.02 & 31.49 \\
\hline $\mathrm{T}_{1} \mathrm{H}_{6}$ & 0.00 & 17.52 & 67.67 & 73.57 & 72.15 \\
\hline $\mathrm{T}_{1} \mathrm{H}_{12}$ & 0.00 & 33.22 & 87.19 & 88.92 & 88.92 \\
\hline $\mathrm{T}_{2} \mathrm{H}_{6}$ & 0.96 & 37.04 & 63.90 & 67.38 & 67.70 \\
\hline $\mathrm{T}_{2} \mathrm{H}_{12}$ & 1.03 & 26.52 & 82.85 & 82.85 & 82.85 \\
\hline $\mathrm{T}_{3} \mathrm{H}_{6}$ & 0.29 & 27.76 & 68.86 & 80.05 & 81.06 \\
\hline $\mathrm{T}_{3} \mathrm{H}_{12}$ & 1.61 & 35.85 & 78.13 & 78.13 & 78.13 \\
\hline $\mathrm{G}_{1} \mathrm{H}_{6}$ & 5.52 & 60.70 & 82.35 & 82.35 & 82.35 \\
\hline $\mathrm{G}_{1} \mathrm{H}_{12}$ & 17.25 & 71.47 & 87.95 & 89.02 & 93.63 \\
\hline $\mathrm{G}_{2} \mathrm{H}_{6}$ & 19.03 & 84.81 & 88.80 & 90.40 & 89.44 \\
\hline $\mathrm{G}_{2} \mathrm{H}_{12}$ & 6.55 & 68.33 & 90.28 & 90.92 & 91.25 \\
\hline $\mathrm{G}_{3} \mathrm{H}_{6}$ & 16.44 & 74.75 & 91.08 & 89.77 & 90.05 \\
\hline $\mathrm{G}_{3} \mathrm{H}_{12}$ & 13.37 & 77.56 & 98.92 & 99.78 & 99.80 \\
\hline $\operatorname{LSD}(0.05)$ & 4.56 & 17.00 & 11.76 & 12.06 & 11.45 \\
\hline CV $(\%)$ & 4.34 & 6.45 & 5.89 & 6.08 & 5.90 \\
\hline
\end{tabular}




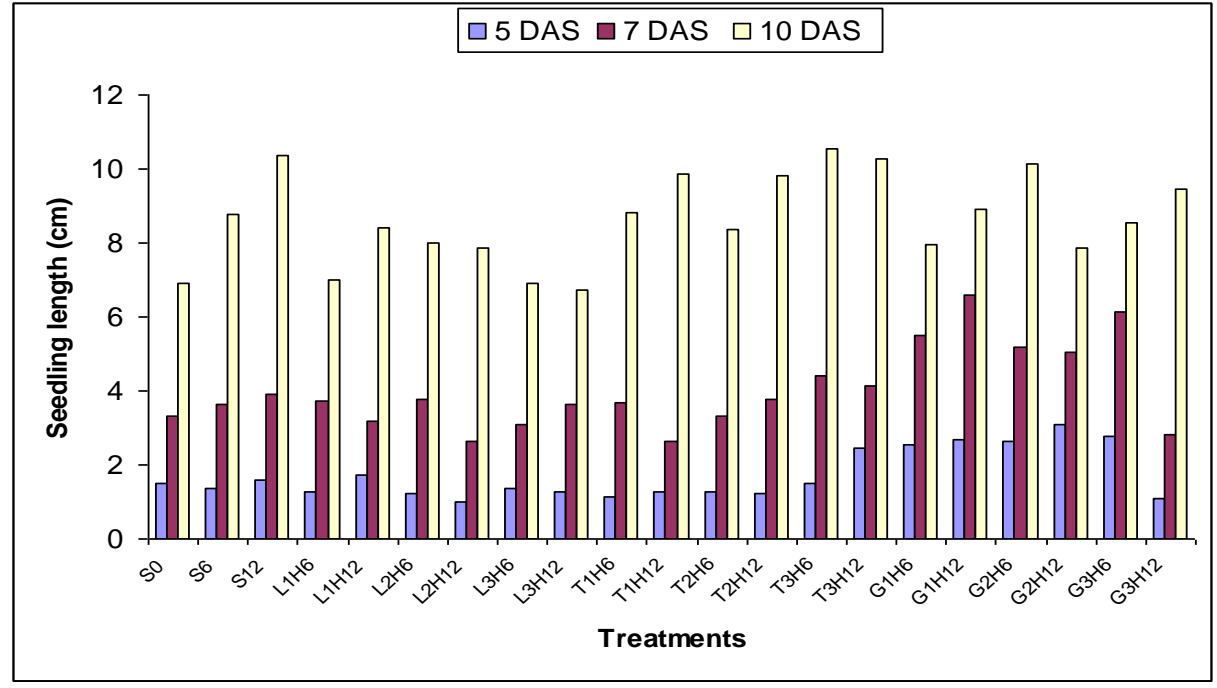

Figure 1. Effect of lemon juice, tamarind leaf extract and gibberellins on seedling length of lentil [LSD (0.05): 1.34, 1.65 and 2.35 at 5, 7 and 10 DAS, respectively]

Table 2. Effect of lemon juice, tamarind leaf extract and gibberellin on final seedling dry matter, vigor index, germination index and speed of germination of lentil at 10 days after setting

\begin{tabular}{l|l|l|l|l}
\hline Treatments & $\begin{array}{l}\text { Final seedling } \\
\text { dry matter } \\
\text { (g/pot) }\end{array}$ & Vigor index & $\begin{array}{l}\text { Germination } \\
\text { index }\end{array}$ & $\begin{array}{l}\text { Speed of } \\
\text { germination } \\
\text { (Number/day) }\end{array}$ \\
\hline $\mathrm{S}_{0}$ & 0.21 & 386.73 & 22.53 & 5.59 \\
$\mathrm{~S}_{6}$ & 0.37 & 779.44 & 38.76 & 8.87 \\
$\mathrm{~S}_{12}$ & 0.33 & 877.48 & 40.17 & 8.46 \\
$\mathrm{~L}_{1} \mathrm{H}_{6}$ & 0.20 & 375.33 & 25.34 & 5.36 \\
$\mathrm{~L}_{1} \mathrm{H}_{12}$ & 0.20 & 504.98 & 25.04 & 6.00 \\
$\mathrm{~L}_{2} \mathrm{H}_{6}$ & 0.18 & 277.86 & 18.09 & 3.48 \\
$\mathrm{~L}_{2} \mathrm{H}_{12}$ & 0.17 & 220.82 & 13.50 & 2.81 \\
$\mathrm{~L}_{3} \mathrm{H}_{6}$ & 0.21 & 358.57 & 19.80 & 5.17 \\
$\mathrm{~L}_{3} \mathrm{H}_{12}$ & 0.18 & 212.26 & 15.20 & 3.15 \\
$\mathrm{~T}_{1} \mathrm{H}_{6}$ & 0.38 & 636.15 & 33.38 & 7.22 \\
$\mathrm{~T}_{1} \mathrm{H}_{12}$ & 0.45 & 877.32 & 44.43 & 8.89 \\
$\mathrm{~T}_{2} \mathrm{H}_{6}$ & 0.34 & 565.04 & 36.62 & 6.77 \\
$\mathrm{~T}_{2} \mathrm{H}_{12}$ & 0.43 & 813.85 & 40.90 & 8.28 \\
$\mathrm{~T}_{3} \mathrm{H}_{6}$ & 0.33 & 855.07 & 38.06 & 8.11 \\
$\mathrm{~T}_{3} \mathrm{H}_{12}$ & 0.34 & 801.43 & 41.50 & 7.81 \\
$\mathrm{G}_{1} \mathrm{H}_{6}$ & 0.32 & 655.02 & 50.74 & 8.23 \\
$\mathrm{G}_{1} \mathrm{H}_{12}$ & 0.34 & 836.45 & 60.36 & 9.36 \\
$\mathrm{G}_{2} \mathrm{H}_{6}$ & 0.37 & 908.03 & 64.20 & 8.94 \\
$\mathrm{G}_{2} \mathrm{H}_{12}$ & 0.31 & 716.28 & 56.43 & 9.12 \\
$\mathrm{G}_{3} \mathrm{H}_{6}$ & 0.31 & 770.86 & 61.18 & 9.01 \\
$\mathrm{G}_{3} \mathrm{H}_{12}$ & 0.38 & 978.86 & 65.75 & 10.37 \\
\hline $\mathrm{LSD}_{2}(0.05)$ & 0.05 & 102.56 & 15.39 & 1.93 \\
\hline $\mathrm{CV}(\%)$ & 5.08 & 6.95 & 7.05 & 5.49 \\
\hline
\end{tabular}




\section{Effect on vigor index of lentil}

The vigor index showed significant source of variation with all treatments. The maximum vigor index was found with $\mathrm{G}_{3} \mathrm{H}_{12}$ (978.86) while the lowest with $\mathrm{L}_{3} \mathrm{H}_{12}$ (212.26). The use of gibberellin and tamarind leaf extract gave better result than lemon juice treated seeds (Table 2).

\section{Effect on germination index of lentil}

The treatment $\left(\mathrm{G}_{3} \mathrm{H}_{12}\right)$ contributed the highest germination index $(65.75)$ while the treatment $\left(\mathrm{L}_{2} \mathrm{H}_{12}\right)$ gave the lowest (15.20) germination index. In this study, all the gibberellin concentrations gave much higher germination index compare the other treatments (Table 2). In comparison to $\mathrm{S}_{0}(22.53)$, the said parameter was improved by soaking seeds in only distilled water with 12 hours, $\mathrm{S}_{12}$ (40.17) which was again improved by all the gibberellin concentrations. However, tamarind leaf extract paid moderate germination index and lemon juice treated seeds gave very low germination index.

\section{Effect on speed of germination of lentil}

The speed of germination showed variation with different treatments. The $\mathrm{S}_{0}$ treatment showed the minimum speed of germination (5.59/day) and the $\mathrm{G}_{1} \mathrm{H}_{12}$ showed the maximum speed of germination (10.37/day). In contrast to $\mathrm{S}_{0}(5.59 /$ day), the speed of germination was improved by soaking seeds in distilled water with 6 hours and 12 hours, which was further improved by the treatments of gibberellin (Table 2).

\section{Conclusion}

It may be concluded that performances of lentil seeds, in terms of different germination and vigor characteristics, were better when growth regulator's components used, and when seeds were soaked by low or medium concentrations among tested all growth regulators combinations. But higher concentration of different growth regulators with defined time schedule may make an insignificant effect in many of those seed germination and vigor parameters, as evidenced in the case of lemon juice of this experiment.

\section{References}

Afzal, M. A., Bakr, M. A. \& Rahman, M. L. (1999). Lentil Cultivation in Bangladesh. Lentil, Blackgram and Mungbean Development Pilot Project, Pulses Research Station, BARI, Gazipur-1701.

Chowdhury, J. U. (1978). Physiology and biochemistry of soybean following GA and IBA application. M. S. Thesis, Dept. of Botany, Dhaka Univ., Dhaka, Bangladesh.

Elias, S. M., Hossain, M. S., Sikder, F. S., Ahmed, J. \& Karim, M. R. (1986). Identification of constraints to pulse production with special reference to present farming systems. Annual Report of the Agricultural Economic Division, BARI, Joydebpur. p. 1.

Gomez, K. A. and Gomez, A. A. (1984). Statistical Procedure for Agricultural Research (2nd edn.). Int. Rice Res. Inst., A Willey Int. Sci., pp. 28-192.

Hussain, Z., Banu, L. A., Azad, A. K. \& Bano, A. (1980). Response of three rice cultivars on gibberellic acid and kinetin applications. Bangladesh. J. Bot. 9(2): 164-166.

Karim, M. F. (2005). Physiological and biochemical responses of chickpea (Cicer arietinum L.) following application of fertilizers and growth regulators. Ph. D. Thesis. Dept. of Botany, Dhaka Univ., Dhaka, Bangladesh. 
Kathiresan, G. \& Balasubramanian, T. N. (1995). Influence of growth regulatory substance on the germination of clip and single budded sets of different age cane. Cooperative Sugars. 26: 695-699.

Lakshmamma, P. \& Rao, I. S. (1996). Response of black gram to shade and naphthalene acetic acid. Indian J. Pl. Physiol. 1(1): 63-64.

Maske, V. G., Deotale, R. D., Sorte, P. N., Tale, N. D. \& Chore, C. N. (1997). Germination, root and shoot studies in chickpea as influenced by $\mathrm{GA}_{3}$ and NAA. Soils and Crops 72(2): 147-149.

Mohanty, S. K. \& Sahoo, N. C. (2006). Effect of soaking period, seed size and growth regulators on imbibition and germination of seeds of some field crops. Orissa J. Agric. Res. Retrived from cababstractsplus.org.

Rahman, M. A. \& Nath, K. K. (1993). Effect of seed treatment of IAA and $\mathrm{GA}_{3}$ on sex expression, fruit character and yield of bottle gourd. Bangladesh J. Sci. 5(2): 57-63.

Renugadevi, J. \& Vijayageetha, V. (2009). Organic seed fortification in cluster bean (cyamopsis tetragonoloba 1.) TAUB. Acta Horticulturae 752: In: International Conference on Indigenous Vegetables and Legumes. Prospectus for Fighting Poverty, Hunger and Malnutrition. Retrived from www.actahort.org.

Uddin, M. M., Quadir, M. A., Choudhury, A. R. \& Choudhury, M. K. (1994). Effects of growth regulators on growth and pod yield of lablab bean grown in summer. Ann. Bangladesh Agric. 4(2): $79-85$.

\section{Citation for this article (APA Style):}

Pulok, M. A. I., Rahman, M. M., Haque, M. N., Chakraborty, R. \& Ali, M. S. (2015). Effect of Growth Regulators on Germination and Vigor of Lentil Seeds. Journal of Bioscience and Agriculture Research 03(01), 08-14.

Retrieved January 15, 2015 from http://www.journalbinet.com/jbar-volume-03-issue-01.html 